\title{
Soroepidemiological survey of chlamydia abortus infection in bovine in the State of Pernambuco, Brazil
}

\section{Inquérito soroepidemiológico da infecção por chlamydia abortus em bovinos no Estado de Pernambuco, Brasil}

\author{
Adalberto Leite da Silva Neto ${ }^{1 *}$; Bruno Pajeú e Silva²; Érica Chaves Lúcio ${ }^{3}$; Sérgio \\ Alves do Nascimento ${ }^{4}$; José Wilton Pinheiro Júnior ${ }^{5}$
}

\section{Highlights}

This is the first record of Chlamydia abortus infection in cattle in Pernambuco.

Of the properties studied, $79.2 \%$ had at least one infected animal.

The prevalence was higher than the percentage observed in national studies

We identified the following risk factors: pasture rent and breeding system.

\begin{abstract}
The objective of this study was to conduct a seroepidemiological survey of Chlamydia abortus infection in dairy cattle herds. A total of 303 blood serum samples were collected from 24 property in Vale do Ipanema microregion in the state of Pernambuco, Brazil. For the diagnosis of $C$. abortus infection, a commercial enzyme immunoassay kit (ELISA) was used. A prevalence of 34.0\% (103/303; 95\% Cl: $28.7 \%-39.7 \%$ ) of infected animals was identified. In 79.8\% (19/24) of the properties, at least one infected animal was detected. The risk factors identified were: semi-intensive system ( $O R=3.47, p \leq 0.000)$, extensive system $(O R=8.14$; $p \leq 0.000)$, supply of water in troughs and directly at the fountain $(O R=2.29, p=0.002)$, pasture rent (OR $=1.72, p=0.041)$, use of artificial insemination (AI) $(O R=3.07, p=0.002)$, and use of Al associated with natural mount $(O R=2.22, p=0.003)$. The occurrence of $C$. abortus infection in dairy cattle in the state of Pernambuco, Brazil, was recorded for the first time. It is concluded that the infection by this agent is present in the analyzed herds and that hygienic and sanitary management measures based on the identified risk factors should be implemented to avoid reproductive losses and losses to the producers.
\end{abstract}

Key words: Reproductive disease. Bacterial infection. Dairy cow.

1 Médico Veterinário Autônomo, M.e em Sanidade e Reprodução de Ruminantes, Recife,PE, Brasil. E-mail: adalbertouag@ hotmail.com

2 Discente do Curso de Doutorado do Programa de Pós-Graduação em Ciência Animal Tropical, Universidade Federal Rural de Pernambuco, UFRPE, Recife, PE, Brasil. E-mail: bruno pajeu@hotmail.com

3 Profa Dra, Universidade Federal da Bahia, UFBA, Salvador, BA, Brasil. E-mail: erica.cl@hotmail.com

4 Dr. em Ciências Veterinária, Departamento de Medicina Veterinária, DMV, Laboratório de Viroses dos Animais Domésticos, UFRPE, Recife, PE, Brasil. E-mail: sergio.correio@gmail.com

5 Prof. Dr., Departamento de Medicina Veterinária, DMV, Medicina Veterinária Preventiva, UFRPE, Recife, PE, Brasil. E-mail: wiltonjrufrpe@gmail.com

* Author for correspondence

Received: May 06, 2020 - Approved: Nov. 04, 2020 


\section{Resumo}

Objetivou-se realizar um inquérito soroepidemiológico da infecção por Chlamydia abortus em rebanhos bovinos leiteiros. Foram coletadas 303 amostras de soro sanguíneo de bovinos procedentes de 24 propriedades da microrregião do Vale do Ipanema no estado de Pernambuco, Brasil. Para o diagnóstico da infecção por C. abortus, utilizou-se kit comercial de ensaio imunoenzimático (ELISA). Foi identificada uma prevalência de 34,0\% (103/303; IC 95\% - 28,7\% - 39,7\%) de animais positivos. Em 79,8\% (19/24) das propriedades foi detectado pelo menos um animal positivo. Os fatores de risco identificados foram: sistema semi-intensivo ( $O R=3,47 ; p=<0,000)$, sistema extensivo $(O R=8,14 ; p=<0,000)$; fornecimento de água em cochos e diretamente na fonte $(O R=2,29 ; p=0,002)$; aluguel de pasto $(O R=1,72 ; p=0,041)$; uso de inseminação artificial $(I A)(O R=3,07 ; p=0,002)$ e uso de IA associado à monta natural $(O R=2,22 ; p=0,003)$. Registra-se, pela primeira vez, a ocorrência da infecção por $C$. abortus em bovinos no estado de Pernambuco, Brasil. Conclui-se que a infecção por esse agente está presente nos rebanhos analisados e que medidas de manejo higiênico-sanitário baseadas nos fatores de risco identificados devem ser implementadas com o intuito de evitar perdas reprodutivas e prejuízos para os produtores.

Palavras-chave: Doença reprodutiva. Infecção bacteriana. Vaca de leite.

\section{Introduction}

Chlamydia abortus (C. abortus) is a obligate intracellular gram-negative bacterium with a coccoid shape, capable of infecting and causing disease in humans, mammals, and birds (Horn, 2015; Seth-Smith et al., 2017).

Chlamydiosis is a disease requiring mandatory notification to the (World Organization for Animal Health [OIE], 2016), with a high prevalence in the dairy cattle population worldwide (Kauffold, Wehrend, \& Sigmarsson, 2014). The disease occurs mostly in Europe and the United States (Niemczuk, 2005), and the interest in this research has been growing due to the occurrence of abortion outbreaks in herds in England since the 1990s (Wilson et al., 2012).

In Brazil, the first isolation was described in the state of Pará in buffalo lungs in a slaughterhouse (Freitas \& Machado, 1988). Later, it was also isolated in bull seminal fluid with vesiculitis (Gomes, Wald, Machado, \& Silveira,
2001). There are only two seroepidemiological studies on cattle chlamydiosis in the country conducted in the states of São Paulo and Paraná (Igayara-Souza et al., 2004; Zacarias et al., 2009).

Some risk factors have already been associated with Chlamydia spp. infection in cattle, such as herds with fewer than 35 matrices, confined or semi-confined herds, no withdrawal of abortion products on pastures, pasture rental (Zacarias et al., 2009), purchase of animals for replacement, use of natural mount, and absence of individual birth pen (Kemmerling, Müller, Mielenz, \& Sauerwein, 2009). The use of disinfectants and the cleanliness of the facilities were considered protective factors (Talafha, Ababneh, Ababneh, \& Al-Majali, 2012).

These bacteria cause reproductive problems among other disorders. The most important are enzootic abortion in goats and sheep, and epizootic in cattle (OIE, 2016). In addition to abortion, there is a common 
occurrence of endometritis, vaginitis, return to heat, irregular estrus, and the increased interval between births (Longbottom \& Coulter, 2003; Godin et al., 2008).

Reproductive disorders that cause abortions and infertility have a negative economic impact on cattle farming and, in some countries, are the main causes of discard in dairy herds (Godin et al., 2008; Wilson et al., 2012). In Brazil, Moura (2012) estimated that an abortion at the end of pregnancy costs approximately $\$ 742.00 /$ cow/year. C. abortus is a pathogen of high economic importance for raising ruminants because it causes such disorders (Seth-Smith et al., 2017).

Thus, the objective of this study was to conduct an epidemiological study of $C$. abortus infection in dairy cattle.

\section{Material and Methods}

\section{Study area}

The study was conducted in the municipalities of Águas Belas, Itaíba, Tupanatinga, Buíque, Pedra, and Venturosa, which make up the microregion of Vale do Ipanema in the Agreste region of Pernambuco, where, according to the Instituto Brasileiro de Geografia e Estatística [IBGE] (2016), 99,872 cows were milked out of a total herd of 210,816 cattle.

\section{Sampling}

The sample of the number of properties composed of 8,001 milk-producing establishments in the municipalities that make up the Vale do Ipanema microregion (IBGE, 2006). Following the average prevalence in studies conducted in Brazil for C. abortus infection (Igayara-Souza et al., 2004; Zacarias et al., 2009), a minimum of 21 properties is required. For this study, 24 properties were selected.

The number of cows in each property (secondary unit) was calculated with the aid of the WinEpi algorithm, using prevalence values of $5.3 \%$ and $1.42 \%$, referencing the studies of Igayara-Souza et al. (2004) and Zacarias et al. (2009), respectively. The studies provided an average prevalence of $3.36 \%$, a statistical error of $8 \%$, and a confidence interval $(\mathrm{Cl})$ of $95 \%$ to calculate the number of properties, totaling 303 animals.

\section{Sample collection and processing}

Blood was collected by coccygeal venipuncture in dairy cows of reproductive age (2 years and above) using vacuum tubes, which were identified and sent to the laboratory to obtain the serum. Subsequently, the samples were frozen at $-20^{\circ} \mathrm{C}$ until their processing.

For the diagnosis of $C$. abortus infection, the samples were submitted to the enzymelinked immunosorbent assay (ELISA), using a commercial kit, following the methodology described by the manufacturer. The results were classified as positive, negative, or inconclusive. For the study of risk factors, inconclusive samples were considered negative.

\section{Questionnaire application}

For the study of risk factors, questionnaires consisting of objective questions were applied, addressing matters about hygienic-sanitary and reproductive management. 


\section{Statistical analysis}

To calculate the prevalence, the dispersion of the relative and absolute frequencies of the results obtained in the serological test were used. To identify the associated risk factors, a univariate analysis of the variables of interest was performed using Pearson's chi-square test or Fisher's exact test, when necessary. Subsequently, a logistic regression analysis was performed, considering the serological exam as a dependent variable (positive or negative). The independent or explanatory variables considered in the model were those that presented statistical significance $<0.20$. This probability was stipulated so that possible risk factors were not excluded from the analysis (Hosmer \& Lemeshow, 1989). The Epi Info 7 program was used to perform statistical calculations.

\section{Spatial characterization}

The coordinates were obtained through the georeferencing of properties using the global positioning system and launched in the QGIS 3.0 software (free geographic information system) for the elaboration of Figure 1. The classification of prevalence obtained as low and high was performed using the SPSS software based on the 25th and 75th percentiles, respectively.

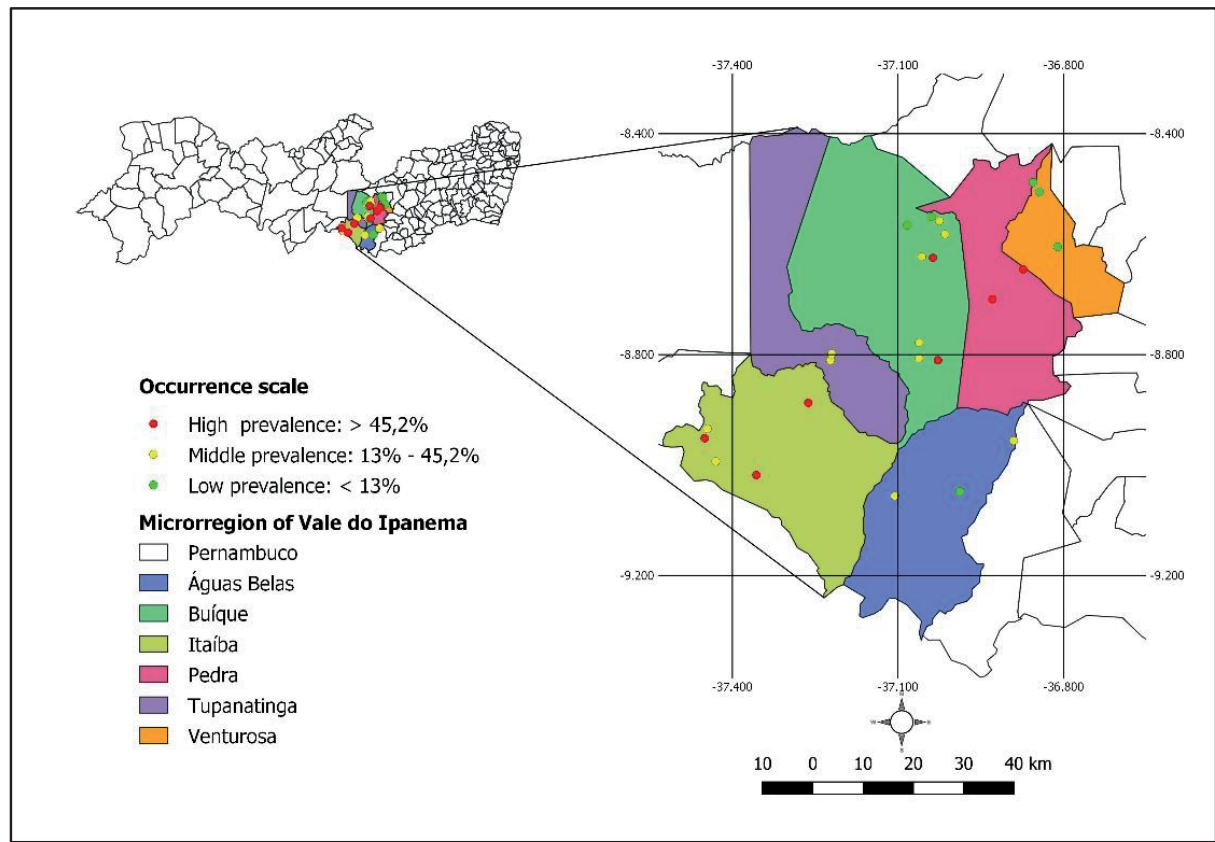

Figure 1. Spatial distribution of the prevalence of infection by Chlamydia abortus in cattle herds in the microregion of Vale do Ipanema microregion in Pernambuco.

\section{Ethical aspects}

The project was approved by the Comissão de Ética no Uso de Animais of the
Universidade Federal Rural de Pernambuco, under license number 34/2017. For the conduct of this research, all applicable ethical principles were respected by the parties involved. 


\section{Results and Discussion}

The occurrence of $C$. abortus infection in dairy cattle in the state of Pernambuco, Brazil, was recorded for the first time. Table 1 shows a prevalence of $34 \%$ in C. abortus infection observed in this study $(103 / 303 ; \mathrm{Cl}$ 28.7-39.7\%), close to the research conducted in Sweden, 28.0\% (Godin et al., 2008) and Poland, 30.1\%) (Czerwińska \& Niemczuk, 2015). In Brazil, the prevalence determined in epidemiological studies is lower than that found in this study. The spatial distribution of $C$. abortus infection in cattle is shown in Figure 1.
The difference in the results found in epidemiological surveys (Igayara-Souza et al., 2004; Zacarias et al., 2009) may be related to management conditions used in different regions in the country in previous studies and to the sample design and diagnostic techniques used, since they used complement fixation as a diagnostic method. Czerwińska and Niemczuk (2015) stated that, although recommended by the OIE, complement fixation presents less diagnostic sensitivity when compared to commercial ELISA tests because complement fixation detects only IgG1 immunoglobulins, which may justify the higher prevalence found in this study.

Table 1

Prevalence of Chlamydia abortus infection in cattle, in Vale do Ipanema microregion in Pernambuco

\begin{tabular}{lccc|}
\hline Result & $\%$ & No. of positives/total & Confidence Interval (CI) \\
\hline Positive & 34.0 & $103 / 303$ & $28.7 \%-39.7 \%$ \\
\hline Negative & 59.7 & $181 / 303$ & $54.0 \%-65.3 \%$ \\
Inconclusive & 6.3 & $19 / 303$ & $3.9 \%-9.8 \%$
\end{tabular}

When analyzing the inconclusive results (6.3\%), one must consider the occurrence of a cross-reaction with gram-negative bacteria that is documented, mainly with Chlamydia pecorum (Buendia et al., 2001; Selim, 2016) to justify such results. However, research must be conducted using direct methods to confirm the real participation of $C$. pecorum in cattle herds since there are no reports of cattle infection by this agent in the literature in Brazil.

Of the 24 properties studied, 19 (79.2\%) had at least one infected animal with a prevalence ranging from 12.5-81.3\%. This high percentage is disturbing from an epidemiological perspective as there is a very intense animal trade in the region. This can also have a significant impact on the spread of the pathogen, given that the health status of herds is not well known. The replacement of animals is a risk factor in free properties of Chlamydia spp. for not knowing the health status and for not performing quarantine with the use of diagnostic tests (Kemmerling et al., 2009).

In this study, the identified risk factors were as follows: system of semi-intensive (OR $=3.47 ; p<0.000)$ and extensive $(O R=8.14 ; p$ $<0.000)$ breeding, and pasture rental $(\mathrm{OR}=1.72$; $\mathrm{p}=0.041$ ) as shown in Tables 2 and 3. These results are partially in accord with those found by Zacarias et al. (2009), who obtained the variables semi-intensive breeding and pasture rent as risk factors for $C$. abortus infection in cattle. 


\section{Table 2}

Analysis of risk factors (general characteristics, food management, and sanitary hygiene) associated with Chlamydia abortus infection in cattle in Vale do Ipanema microregion in Pernambuco

\begin{tabular}{|c|c|c|c|c|c|c|}
\hline \multirow{2}{*}{ Variable } & \multirow{2}{*}{ No. } & \multirow{2}{*}{$\begin{array}{c}\text { ELISA } \\
\text { (Positive) }\end{array}$} & \multirow{2}{*}{$p$ value } & \multicolumn{3}{|c|}{ Logistic Regression } \\
\hline & & & & OR & Cl (95\%) & $\mathrm{p}$ value \\
\hline \multicolumn{7}{|l|}{ Breeding system } \\
\hline Intensive & 67 & 10 (14.9\%) & \multirow{3}{*}{$<0.000$} & & - & \\
\hline Semi-intensive & 219 & 83 (37.9\%) & & 3.47 & $1.68-7.18$ & $<0.000$ \\
\hline Extensive & 17 & 10 (58.8\%) & & 8.14 & $2.51-26.41$ & $<0.000$ \\
\hline \multicolumn{7}{|l|}{ Common troughs } \\
\hline Yes & 30 & 16 (46.7\%) & \multirow{2}{*}{0.091} & \multirow{2}{*}{1.80} & \multirow{2}{*}{$0.84-3.87$} & \multirow{2}{*}{0.126} \\
\hline No & 273 & 184 (32.6\%) & & & & \\
\hline \multicolumn{7}{|l|}{ Water source } \\
\hline Running water & 19 & 6 (31.6\%) & \multirow{3}{*}{0.016} & & - & \\
\hline Still water & 176 & 49 (27.8\%) & & 0.83 & $0.30-2.32$ & 0.731 \\
\hline Both & 108 & 48 (44.4\%) & & 1.73 & $0.61-4.89$ & 0.299 \\
\hline \multicolumn{7}{|l|}{ Water supply } \\
\hline Trough & 155 & 40 (25.8\%) & \multirow{3}{*}{0.006} & & - & \\
\hline Fountain & 42 & 16 (38.1\%) & & 1.76 & $0.86-3.63$ & 0.120 \\
\hline Both & 106 & 47 (44.3\%) & & 2.29 & $1.35-3.87$ & 0.002 \\
\hline \multicolumn{7}{|c|}{ Animals purchased for replacement } \\
\hline Yes & 138 & 44 (31.9\%) & \multirow{2}{*}{0.278} & & & \\
\hline No & 165 & 59 (35.8\%) & & & & \\
\hline \multicolumn{7}{|l|}{ Origin of animals } \\
\hline Free fair & 7 & $2(28.6 \%)$ & \multirow{3}{*}{0.653} & & & \\
\hline Neighbor herds & 93 & 32 (34.4\%) & & & & \\
\hline Others & 38 & $10(26.3 \%)$ & & & & \\
\hline \multicolumn{7}{|c|}{ Performs quarantine } \\
\hline Yes & 8 & $1(12.5 \%)$ & \multirow{2}{*}{0.211} & & & \\
\hline No & 130 & $43(33.1 \%)$ & & & & \\
\hline \multicolumn{7}{|l|}{ Pasture rent } \\
\hline Yes & 118 & 45(38.1\%) & \multirow{2}{*}{0.137} & \multirow{2}{*}{1.72} & \multirow{2}{*}{$1.02-2.92$} & \multirow{2}{*}{0.041} \\
\hline No & 185 & $58(31.3 \%)$ & & & & \\
\hline \multicolumn{7}{|c|}{ Lends grazing to third parties } \\
\hline Yes & 42 & $18(42.9)$ & 0.129 & 193 & $0.94-3.93$ & 0.070 \\
\hline No & 261 & 85 (32.6) & & & & \\
\hline Presence of floo & & & & & & \\
\hline Yes & 172 & $53(30.8 \%)$ & 0112 & 138 & $085-223$ & 181 \\
\hline No & 131 & $50(38.2 \%)$ & 0.172 & 1.00 & $0.03-2.20$ & 0.101 \\
\hline
\end{tabular}




\section{Table 3}

Analysis of risk factors (reproductive management) associated with Chlamydia abortus infection in cattle in Vale do Ipanema microregion in Pernambuco

\begin{tabular}{|c|c|c|c|c|c|c|}
\hline \multirow{2}{*}{ Variable } & \multirow{2}{*}{ No. } & \multirow{2}{*}{$\begin{array}{c}\text { ELISA } \\
\text { (Positive) }\end{array}$} & \multirow{2}{*}{$p$ value } & \multicolumn{3}{|c|}{ Regressão Logística } \\
\hline & & & & OR & $\mathrm{Cl}(95 \%)$ & $p$ value \\
\hline \multicolumn{7}{|l|}{ Reproductive management } \\
\hline Natural mount & 176 & $45(25.6 \%)$ & \multirow{3}{*}{$<0.000$} & & - & \\
\hline Artificial Insemination (Al) & 37 & 19 (51.4\%) & & 3.07 & $1.48-6.36$ & 0.002 \\
\hline Use of Al-associated with natural mount & 90 & 39 (43.3\%) & & 2.22 & $1.30-3.80$ & 0.003 \\
\hline \multicolumn{7}{|l|}{$\begin{array}{l}\text { Features animals with a history of } \\
\text { reproductive problems }\end{array}$} \\
\hline Yes & 276 & 91 (33.0\%) & \multirow{2}{*}{0.161} & \multirow{2}{*}{1.62} & \multirow{2}{*}{$0.73-3.61$} & \multirow{2}{*}{0.233} \\
\hline No & 27 & $12(44.4 \%)$ & & & & \\
\hline \multicolumn{7}{|l|}{ Abortion historic } \\
\hline Yes & 234 & 80 (34.2\%) & \multirow{2}{*}{0.202} & & & \\
\hline No & 42 & $11(26.2 \%)$ & & & & \\
\hline \multicolumn{7}{|l|}{ Period when abortion occurs } \\
\hline $1 / 3$ & 39 & 15 (38.5\%) & \multirow{3}{*}{0.102} & & - & \\
\hline $2 / 3$ & 114 & 41 (36.0\%) & & 0.89 & $0.42-1.90$ & 0.780 \\
\hline $3 / 3$ & 64 & 14 (21.9\%) & & 0.44 & 0.18-1.07 & 0.072 \\
\hline \multicolumn{7}{|l|}{$\begin{array}{l}\text { Isolation of animals with reproductive } \\
\text { diseases }\end{array}$} \\
\hline Yes & 19 & 6 (31.6\%) & \multirow{2}{*}{0.557} & & & \\
\hline No & 257 & 85 (33.1\%) & & & & \\
\hline
\end{tabular}

It is known that the main form of transmission of $C$. abortus occurs through contaminated water and food ingestion by elementary bodies eliminated in placental remains and uterine discharges (Longbottom \& Coulter, 2003). In addition, the agent is remarkably resistant to dry, cool, and lightsheltered conditions (Reinhold, Sachse, \& Kaltenboeck, 2011). The conditions mentioned are common in the studied region, and more favorable conditions were observed mainly around water and food troughs as well as shading areas, where the removal of feces is not frequent, and its accumulation allows the creation of a favorable environment for the maintenance of $C$. abortus.

Pasture rental, a common practice in the region during rainy periods, may favor not only the transmission of C. abortus, but also other pathogenic microorganisms through contact with animals from different properties with unknown health status. These animals can act as sources of infection (Zacarias et al., 2009); therefore, pasture rental is not recommended. Another point to be highlighted as a risk factor is the supply of water, both in the trough and directly at the fountain $(\mathrm{OR}=2.29 ; \mathrm{p}=0.002)$. Beyond these issues, 
dessedentation habits and the method water is offered to animals can be closely linked to the transmission of the agent. Chlamydia spp. manage to survive in water for an expressive time (Reinhold et al., 2011; Talafha et al., 2012). In the sampled properties, it was possible to identify places of dessedentation that provide these conditions of survival for the bacteria. The animals generally drink from small wells of water formed in the pastures or in troughs where there is accumulation of feces and mud and a maintained microclimate that favors the survival of this microorganism.

Regarding reproductive management, the use of artificial insemination (Al) (OR = 3.07; $p=0.002$ ) and properties that use the Al technique associated with natural mount $(O R=2.22 ; p=0.003)$ were considered as risk factors. Research has shown the presence of this bacterium in semen (Gomes et al., 2001) and its potential for transmission (Teankum et al., 2007; Karlsson, Alenius, Björkman, Persson, \& Englund, 2010; Kauffold et al., 2014). Kemmerling et al. (2009) affirm that a herd is more susceptible when using natural mount, as bulls usually spend more time on the properties and cover a larger number of cows, which increases the chances of spreading the agent within the herd. Since the tests for detection of Chlamydia spp. are not included in the sanitary requirements for semen collection and processing of the OIE (2017), the inclusion of this agent in the laboratory testing routine of breeders at insemination centers can be of great value. It is important to note that cryopreservation does not eliminate the bacteria (Storz, Carroll, Stephenson, Ball, \& Eugster, 1976).
Regarding the history of abortions on the properties, there was no significant association with $C$. abortus infection ( $p=$ 0.202). However, there was a greater number of seropositive animals on properties that had a history of abortion (34.2\%). This result is in accord with those found by Cavirani et al. (2001), Wang, Shieh and Liao (2001), and Wehnred, Failing, Hauser, Jäger and Bostedt (2005), who obtained a higher percentage of infected animals in bovine herds with a history of abortion. This result suggests that $C$. abortus may be important in the etiology of abortions in the studied herds. Research using direct diagnostic methods, such as polymerase chain reaction and immunohistochemistry, should be carried out to confirm the real participation of the agent in cases of abortion (Sachse et al., 2009).

Another point to be highlighted is that there are no commercially available vaccines against the agent Chlamydia spp. in cattle on the market, nationally and internationally, and accredited laboratories conducting this diagnosis on a commercial scale in Brazil. Therefore, it is suggested that epidemiological studies be carried out at the national level to determine the real economic impact that this agent may have on the beef and cattle production chain, to support control and prevention programs. Public health services need to be alerted as it is a zoonotic disease. Studies should be conducted in an attempt to isolate the bacterium in abortions to prove its direct action in these cases and apply hygienic-sanitary management measures based on the identified risk factors to avoid probable reproductive and financial losses for producers. 


\section{Conclusion}

It is concluded that $C$. abortus infection occurs in dairy cattle.

\section{Acknowledgments}

To the Coordenação de Aperfeiçoamento de Pessoal de Nível Superior (CAPES) for granting a master's scholarship to the first author.

\section{References}

Buendia, A. J., Cuello, F., Del Rio, L., Gallego, M. C., Caro, M. R., \& Salinas, J. (2001). Field evaluation of a new commercially available ELISA based on a recombinant antigen for diagnosing Chlamydophila abortus (Chlamydia psittaci serotype 1) infection. Veterinary Microbiology, 78(3), 229-239. doi: 10.1016/s0378-1135(00)00298-4

Cavirani, S., Cabassi, C. S., Donofrio, G., De laco, B., Taddey, S., \& Flammini, C. F. (2001). Association between Chlamydia psittaci seropositivity and abortion in Italian dairy cows. Preventive Veterinary Medicine, 50(1-2), 145-151. doi: 10.1016/s01675877(01)00197-0

Czerwińska, M. S., \& Niemczuk, K. (2015). Preliminary study in range of prevalence Chlamydia spp. in the polish cattle population. Journal for Veterinary Medicine, Biotechnology and Biosafety, 1(3), 5-9.

Freitas, J.A., \& Machado, R. D. (1988). Isolamento de Chlamydia psittaci em búfalos abatidos para consumo em Belém, Pará. Pesquisa Veterinária Brasileira, 8(3-4), 43-50.
Godin, A. C., Björkman, C., Englund, S., Johansson, K. E., Niskanen, R., \& Alenius, S. (2008). Investigation of Chlamydophila spp. in dairy cows with reproductive disorders. Acta Veterinaria Scandinavica, 39(50), 1-6. doi: 10.1186/1751-0147-50-39

Gomes, M. J. P. O., Wald, V. B. O., Machado, R. D. O., \& Silveira, M. C. (2001). Isolamento de Chlamydia psittaci em touros com vesiculite seminal, no Rio Grande do Sul. $A$ Hora Veterinária, 119, 43-46.

Horn, M. (2015). Chlamydia. In C. C. Kuo, R. S. Stephens, M. P. Bavoil, \& B. Kaltenboeck. Berguey's manual of systematics of archaea and bacteria. [s.e.]: Berguey's Manual Trust. Retrieved from https:// onlinelibrary.wiley.com/doi/ abs/10.1002/9781118960608

Hosmer, D. W., \& Lemeshow, S. (1989). Applied logistic regression (3nd ed.). New York: John Wiley \& Sons.

Igayara-Souza, C. A., Genovez, M. E., Ferreira, F., Paulin, L. M., Scarelli, E., Cardoso, M. V., \& Turilli, C. (2004). Ocorrência de anticorpos anti-Chlamydophila em bovinos e sua relação com distúrbios reprodutivos. Revista Brasileira de Reprodução Animal, 28(1), 28-33.

Instituto Brasileiro de Geografia e Estatística (2006). Censo agropecuário 2006. Recuperado de http://www. ibge.com.br

Instituto Brasileiro de Geografia e Estatística (2016). Produção da pecuária municipal 2015. Recuperado de http://www.ibge. com.br

Karlsson, A.C., Alenius, S., Björkman, C.,Persson, Y., \& Englund, S. (2010). Investigation of Chlamydiaceae in semen and cauda epididymidis and seroprevalence of Chlamydophila abortus in breeding bulls. Acta Veterinaria Scandinavica, 52(2), 1-4. doi: 10.1186/1751-0147-52-2 
Kauffold, J., Wehrend, A., \& Sigmarsson, H. (2014). Chlamydia and Chlamydophila in bovine reproduction. Clinical Theriogenology, 6(3), 251-254.

Kemmerling, K., Müller, U., Mielenz, M., \& Sauerwein, H. (2009). Chlamydophila species in dairy farms: Polymerase chain reaction prevalence, disease association, and risk factors identified in a crosssectional study in western Germany. Journal of Dairy Science, 92(9), 43474354. doi: 10.3168/jds.2009-2051

Longbottom, D., \& Coulter, L. J. (2003). Animal chlamydioses and zoonotic implications. Journal of Comparative Pathology, 128(4), 217-244. doi: 10.1053/jcpa.2002.0629

Moura, F. T. (2012). Quanto custa o aborto? Jornal da Produção de Leite, 21(280), 1.

Niemczuk, K. (2005). Prevalence of antibodies against Chlamydophila psittaci and Chlamydophila abortus in cattle in Poland. A preliminary report. Bulletin of the Veterinary Institute in Pulawy, 49(3), 293297.

Reinhold, P., Sachse, K., \& Kaltenboeck, B. (2011). Chlamydiaceae in cattle, commensals, trigger organism, or pathogens? The Veterinary Journal, 189(3), 257-267. doi: 10.1016/j.tvjl.2010.09.003

Sachse, K., Vretou, E., Livingstone, M., Borel, N., Pospischil, A., \& Longbottom, D. (2009). Recent developments in the laboratory diagnosis of chlamydial infections. Veterinary Microbiology, 135(1-2), 2-21. doi: 10.1016/j.vetmic.2008.09.040

Selim, A. (2016). Chlamydophila abortus infection in small ruminants: a review. Asian Journal of Animal and Veterinary Advances, 11(10), 587-593. doi: 10.3923/ ajava.2016.587.593
Seth-Smith, H. M. B., Busó, L. S., Livingstone, M., Sait, M., Harris, S. R., Aitchison, K. D.,... Thomson, N. R. (2017). European Chlamydia abortus livestock isolate genomes reveal unusual stability and limited diversity, reflected in geographical signatures. Biomed Central Genomics, 18(344), 1-10. doi: 10.1186/s12864-0173657-y

Storz, J., Carroll, E. J., Stephenson, E. H., Ball, L., \& Eugster, A. K. (1976). Urogenital infection and seminal excretion after inoculation of bulls and rams with Chlamydial. American Journal of Veterinary Research, 37(5), 517-520.

Talafha, A. Q., Ababneh, M. M., Ababneh, M. M., \& Al-Majali, A. M. (2012). Prevalence and risk factors associated with Chlamydophila abortus infection in dairy herds in Jordan. Tropical Animal Health and Production, 44(8), 1841-1846. doi: 10.1007/s11250012-0146-9

Teankum, K., Pospischil, A., Janett, F., Brugnera, E., Hoelzle, L. E., Hoelzle, K.,... Borel, N. (2007). Prevalence of chlamydiae in semen and genital tracts of bulls, rams and bucks. Theriogenilogy, 67(1), 303-310. doi: 10.1016/j.theriogenology.2006.07.012

Wang, F. I., Shieh, H., \& Liao, Y. K. (2001). Prevalence of Chlamydophila abortus infection in domesticated ruminants in Taiwan. Journal of Veterinary Medical Science, 63(11), 1215-1220. doi: 10.1292/ jvms. 63.1215

Wehnred, A., Failing, K., Hauser, B., Jäger, C., \& Bostedt, H. (2005). Production, reproductive, and metabolic factors associated with chlamydial seropositivity and reproductive tract antigens in dairy herds with fertility disorders. Theriogenology, 63(3), 923-930. doi: 10.1016/j.theriogenology.2004.05.009 
Wilson, K., Sammin, D., Harmeyer, S., Nath, M., Livingstone, M., \& Longbottom, D. (2012). Seroprevalence of chlamydial infection in cattle in Ireland. The Veterinary Journal, 193(2), 583-585. doi: 10.1016/j. tvjl.2011.12.018

World Organization for Animal Health - OIE (2016). Terrestrial manual. Retrieved from http://www.oie.int

World Organization for Animal Health - OIE (2017). Terrestrial animal health code. Retrieved from http:// www.oie.int
Zacarias, F. G. S., Spohr, K. A. H., Lima, B. A. C., Dias, J. A., Müller, E. E., Ferreira, J. S., Neto,... Freitas, J. C. (2009). Prevalência de anticorpos anti-Chlamydophila spp. em propriedades rurais com histórico de aborto bovino no estado do Paraná. Pesquisa Veterinária Brasileira, 29(3), 215-219. doi: 10.1590/S0100$736 \times 2009000300005$ 
